\title{
IMPLEMENTASI UNDANG-UNDANG KETENAGAKERJAAN DALAM PERJANJIAN KERJA ANTARA PERUSAHAAN DAN TENAGA KERJA DI PERSEROAN TERBATAS (PT)
}

\author{
Yuliana Yuli W, Sulastri, Dwi Aryanti R \\ Universitas Pembangunan Nasional Veteran Jakarta \\ Jl. RS. Fatmawati No. 1, Pondok Labu Jakarta Selatan 12450 \\ Email: yuli080706@gmail.com
}

\begin{abstract}
Abstrak
Perjanjian Kerja adalah Perjanjian atau kesepakatan yang diadakan antara serikat pekerja atau serikat-serikat pekerja yang telah terdaftar pada departemen tenaga kerja dengan pengusaha atau perkumpulan pengusaha yang berbadan hukum, yang pada umumnya atau semata-mata memuat syarat-syarat kerja yang harus diperhatikan dalam perjanjian kerja. Perumusan masalah dalam penelitian ini adalah bagaimana Pelaksanaan Perjanjian Kerja Di Perseroan Terbatas Ditinjau Dari Peraturan PerundangUndangan Ketenagakerjaan dan apakah Perjanjian Kerja Yang Dibuat Oleh Perseroan Terbatas (PT) Dengan Pekerja Telah Memenuhi Unsur-Unsur Perjanjian Kerja Menurut Undang-Undang Nomor 13 Tahun 2003 Tentang Ketenagakerjaan. Metode penelitian yang digunakan yakni: studi kepustakaan (library research) dan penelitian lapangan (field research). Hasil penelitian ini, menyimpulkan bahwa saat ini masih terdapat beberapa perusahaan yang masih mencantumkan dalil-dalil perjanjian kerja antara perusahaan dan karyawan yang bertentangan dengan Undang-Undang Nomor 13 Tahun 2003 Tentang Ketenagakerjaan, yaitu apabila salah satu perusahaan tidak membayarkan cuti karyawan yang belum diambil atau gugur, maka karyawan berhak mendapatkan uang penggantian hak sesuai dengan ketentuan perundang-undangan.
\end{abstract}

\section{Kata kunci: Ketenagakerjaan, Perjanjian Kerja, Undang-Undang Ketenaga ker- jaan}

\begin{abstract}
Employment Agreement is an Agreement or agreement that is established between a union or trade unions that have been registered with the labor department with employers or associations of entrepreneurs who are legal entities, which in general or merely contain work conditions that must be considered in the employment agreement. The formulation of the problem in this study is how the implementation of the employment agreement in a limited company is reviewed from the labor legislation and whether the work agreement made by a limited liability company (PT) with the worker has fulfilled the elements of the employment agreement according to Law No. 13 of 2003 concerning Employment. The research method uses literature study and field research. The results of this study conclude that currently there are still several companies that still include the arguments of work agreements between companies and employees that are contrary to Law Number 13 of 2003 concerning Manpower, namely if one company does not pay employee leave that has not been taken or fall, then the employee has the right to get compensation money in accordance with the provisions of the law.
\end{abstract}

Keywords: Labor, Employment Agreement, Employment Laws 


\section{A. PENDAHULUAN}

\section{Latar Belakang}

Ketenagakerjaan merupakan bagian yang tidak bisa dipisahkan dari pembangunan nasional yang berdasarkan Pancasila dan Undang-Undang Dasar Negara Republik Indonesia tahun 1945. Tenaga kerja mempunyai peranan, kedudukan yang sangat penting sebagai pelaku dan sasaran pembangunan nasional. Hak-hak tenaga kerja yang diatur dalam Peraturan Ketenagakerjaan Indonesia, yang didalamnya termasuk perlindungan tenaga kerja merupakan hal yang harus diperjuangkan agar harkat dan kemanusiaan tenaga kerja ikut terangkat. Perlindungan tenaga kerja dimaksudkan untuk menjamin hak-hak dasar karyawan dengan tetap mem perhatikan perkembangan kemajuan dunia usaha Nasional dan Internasional. Sebagaimana disebutkan dalam Pasal 28 D Undang-Undang Dasar Tahun 1945 bahwa setiap orang berhak untuk bekerja serta mendapatkan imbalan atau perlakuan yang adil dan layak dalam hubungan kerja. ${ }^{1}$

Tujuan perlindungan tenaga kerja adalah untuk menjamin berlangsungnya sistem hubungan kerja secara harmonis tanpa disertai adanya tekanan dari pihak yang kuat kepada pihak yang lemah. ${ }^{2}$ Sebagaimana disebutkan dalam Pasal 28 D Undang-Undang Dasar Tahun 1945 bahwa setiap orang berhak untuk bekerja serta mendapatkan imbalan atau perlakuan yang adil dan layak dalam hubungan kerja.

Karyawan dalam sebuah Perusahaan biasanya didefinisikan sebagai para Pekerja yang memiliki jabatan struktural. Mereka bekerja di bawah komando para Manajer atau Supervisor, karena pada umumnya mereka mengenyam pendidikan yang sedang dan tinggi, kendatipun posisinya dalam pengambilan keputusan cukup besar kepada karyawan yang mendominasi jumlah terbesar di dalam Perusahaan. Umumnya karena struktural posisi karyawan di tingkat yang rendah, maka seringkali karyawan di suatu Perusahaan membentuk kelompok informal atau serikat untuk membela kepentingan mereka. Pada saat mereka menyatu, mereka akan sangat sensitif. ${ }^{3}$

Di Perseroan Terbatas (PT) pernah terjadi perselisihan antara tenaga kerja dengan perusahaan, diantaranya adalah mengenai pemberian sanksi kepada tenaga kerja yang melakukan pelanggaran dalam waktu kerja. Tenaga kerja bekerja tidak sesuai dengan

\footnotetext{
F. Winarni, Administrasi Gaji dan Upah, Yogyakarta: Pustaka Widyatama, 2006, hlm. 89.

2 Abdul Khakim, Dasar-Dasar Hukum Ketenagakerjaan Indonesia, Bandung: PT Citra Aditya Bakti, 2014, hlm. 99.

3 Hardijan, Hukum Ketenagakerjaan, Jakarta: Ghalia Indonesia, 2004, hlm. 45.
} 
waktu kerja yang telah ditentukan perusahaan, seperti terlambat datang ke kantor hampir setiap hari dalam seminggu. Sehingga pihak perusahaan melakukan pemanggilan kepada tenaga kerja yang melanggar ketentuan tersebut dan melakukan peneguran agar kembali mematuhi peraturan perusahaan. Namun, pada saat terjadi kasus itu, peraturan mengenai ketentuan waktu kerja belum diatur secara tertulis dalam perjanjian kerja, sehingga tenaga kerja tidak terlalu mengindahkan ketentuan tersebut. Oleh karena itu, pihak perusahaan kemudian mencantumkan ketentuan mengenai waktu kerja tenaga kerja beserta dengan penyelesaian perselisihan antara perusahaan dengan tenaga kerja agar sistem kinerja Perusahaan lebih teratur.

Adanya peraturan tertulis mengenai waktu kerja yang tertuang dalam Perjanjian Kerja, maka tenaga kerja dapat lebih mengetahui kewajiban yang harus dilaksanakan dalam bekerja. Selain itu, tenaga kerja juga tidak dapat dikenakan sanksi oleh perusahaan terhadap perbuatan-perbuatan yang tidak tertulis aturannya dalam Perjanjian Kerja. Sehingga, dengan adanya Perjanjian Kerja di Persoran Terbatas (PT) dapat memberikan perlindungan hukum kepada tenaga kerja di perusahaan tersebut.

\section{Rumusan Masalah}

Berdasarkan uraian latar belakang diatas, maka pemasalahan dalam penelitian ini dirumuskan tentang bagaimana pelaksanaan perjanjian kerja di Perseroan Terbatas ditinjau dari Peraturan Perundang-Undangan Ketenagakerjaan dan apakah terpenuhi atau tidaknya unsur-unsur perjanjian kerja menurut Undang-undang Nomor 13 Tahun 2003 tentang Ketenagakerjaan dalam Perjanjian kerja Antara Perseroan Terbatas (PT) dengan Pekerja.

\section{B. PEMBAHASAN}

\section{Pelaksanaan Perjanjian Kerja Di Perseroan Terbatas Ditinjau Dari Peraturan Perundang-Undangan Ketenagakerjaan.}

Perjanjian dapat diartikan sebagai suatu perbuatan yang mana salah satu orang atau lebih mengikatkan dirinya terhadap satu orang lain atau lebih. ${ }^{4}$ Ini berarti bahwa dalam suatu Perjanjian tercipta kewajiban yang harus dipenuhi oleh satu orang kepada orang lainnya yang berhak atas pemenuhan kewajiban tersebut. Dengan kata lain,

\footnotetext{
$4 \quad$ Kitab Undang-Undang Hukum Perdata (Burgerlijk Wetboek), Pasal 1313
} 
bahwa dalam suatu Perjanjian akan selalu ada dua pihak, dimana pihak yang satu wajib memenuhi kewajiban-kewajiban yang tertera dalam perjanjian dan pihak lain berhak atas kewajiban tersebut. ${ }^{5}$ Perjanjian adalah suatu peristiwa dimana kedua pihak itu setuju untuk melakukan sesuatu (prestasi). Dapat dikatakan, bahwa dua pihak yang saling bersepakat tersebut menerima prestasi dan saling memberi kontraprestasi.

Salah satu bentuk Perjanjian yang sering dipraktekkan dalam masyarakat adalah Perjanjian Kerja yang dilakukan antara Pemberi Kerja/Perusahaan dengan Pekerjanya. Menurut Undang-Undang Nomor 13 Tahun 2003, Perjanjian Kerja adalah Perjanjian antara Pekerja atau Buruh dengan Perusahaan atau Pemberi Kerja yang termuat syaratsyarat hak dan kewajiban para pihak. Perjanjian kerja pada dasarnya dibuat untuk mengantisipasi timbulnya permasalahan atau mencegah terjadinya perselisihan/sengketa yang kemungkinan dapat terjadi antara para pihak yang terlibat dalam suatu hubungan kerja yakni pihak pertama (Perusahaan) dan pihak kedua yang disebut (Pekerja atau Buruh).

Di dalam membuat naskah Perjanjian Kerja harus memuat unsur-unsur dan syaratsyarat yang telah ditentukan didalam membuat suatu naskah Perjanjian Kerja, agar naskah tersebut dapat mempunyai kekuatan hukum yang sah diantara para pihak, termasuk memenuhi ketentuan mengenai pencatatan Perjanjian Kerja pada pemerintah, Dinas Tenaga Kerja setempat.

Oleh karena seringnya timbul permasalahan dalam hubungan kerja, maka perlu melibatkan Pemerintah sebagai pihak yang memfasilitasi, sehingga lahirlah istilah Hubungan Industrial. Hubungan Industrial merupakan suatu sistem hubungan yang terbentuk antara pelaku dalam proses produksi barang dan/atau jasa yang terdiri dari unsur Pengusaha, Pekerja dan Pemerintah yang didasarkan pada nilai-nilai Pancasila dan Undang-Undang Dasar 1945.6 Hubungan Industrial adalah keseimbangan antara tujuan dan kepentingan bagi Pekerja dan Pengusaha dalam proses produksi barang dan jasa di Perusahaan. Artinya para Pekerja dan Pengusaha secara individu dan kolektif mempunyai tujuan dan tanggung jawab yang sama, karena dengan sukses hubungan industrial, baik Pekerja maupun Pengusaha sama-sama akan mendapat manfaat, baik secara individual maupun bagi Organisasi Perusahaan.

\footnotetext{
hlm. 1

6 Indonesia, Undang-Undang No.13 tahun 2003 tentang Ketenagakerjaan, Pasal 1 angka 16.
}

5 Tagor Simanjuntak, Draft Surat Perjanjian Segala Urusan, Yogyakarta: Aksara Sukses, 2014, 
Pelaksanaan Hubungan Industrial di Perusahaan selalu dipengaruhi oleh dinamika masyarakat sehingga dalam pelaksanaannya selalu menghadapi tantangan dan rintangan dan berpengaruh pada kondisi hubungan kerja yang selalu berubah dari waktu ke waktu. Secara garis besar, permasalahan yang terjadi dalam hubungan kerja berpengaruh kepada hubungan industrial, antara lain meliputi pemahaman teknis mengenai UndangUndang bidang Hubungan Industrial tentang hakekat hubungan kerja, mengenai permasalahan Perjanjian Kerja yang menjadi dasar lahirnya hubungan kerja yang mengatur tentang hak dan kewajiban para pihak, dan upaya-upaya perbaikan syarat kerja yang diatur dalam ketentuan normatif.

Aloysius Uwiyono memandang hubungan kerja dalam konteks hukum Indonesia adalah bahwa hubungan kerja berkaitan dengan hubungan kontraktual yang dibuat antara Pekerja dengan Pengusaha. ${ }^{7}$ Oleh karenanya hubungan kerja didasarkan pada perjanjian kerja yang mengatur syarat-syarat kerja, hak dan kewajiban suatu tata tertib di Perusahaan yang terinci dalam perjanjian kerja bersama atau peraturan Perusahaan. Hubungan hukum yang berdasarkan pada hubungan kontraktual sebenarnya telah dianut di Indonesia sejak berlakunya Burgerlijk Wetboek (BW) atau yang lazim sekarang disebut dengan Kitab Undang-Undang Hukum Perdata (KUHPerdata). Berdasarkan prinsip kebebasan berkontrak dalam Hukum Perdata/Hukum Privat dinyatakan, bahwa siapapun yang memenuhi syarat berhak melakukan perjanjian dengan pihak lain, dan perjanjian tersebut berlaku sebagai Undang-Undang bagi para pihak yang membuatnya (pacta sun servanda). ${ }^{8}$

Dalam setiap kontrak yang dibuat, terlebih dahulu harus ada beberapa syarat yang harus dipenuhi, agar kontrak yang akan atau telah dibuat secara sah dan dapat dipertanggung jawabkan. ${ }^{9}$ Dalam hukum perburuhan di Indonesia, harus dibedakan antara Hubungan Kerja dengan Hubungan Industrial. Beberapa negara baik yang termasuk di dalam sistem hukum Kontinental (Continental Law) maupun Common Law membedakan kedua bentuk hubungan ini. Hubungan hukum antara Pengusaha dengan Pekerja lahir sebagai akibat adanya perjanjian kerja, baik yang dibuat tertulis maupun secara lisan. Perjanjian kerja secara tertulis biasanya telah disiapkan oleh Pengusaha

7 "Hubungan Kerja dan Perjanjian Kerja dalam Perspektif Hubungan Industrial", http://sekartrisakti.wordpress.com, diakses tanggal 24 September 2014.

$8 \quad$ Kitab Undang-Undang Hukum Perdata (Burgerlijk Wetboek), pasal 1338.

9 Richard Burton Simatupang, Aspek Hukum dalam Bisnis, Jakarta: Rineka Cipta, 2007, hlm. 28. 
sehingga isinya menguntungkan pihak Pengusaha tetapi memberatkan Pekerja, perjanjian seperti ini disebut sebagai perjanjian baku.

Judge Bartolome' Rios Salmeron mengatakan, bahwa hubungan kerja (labour relationship) selalu didasarkan pada adanya Perjanjian Kerja (labour contract). Sedangkan Bruce E.Kaufmann menggaris bawahi, bahwa walaupun di Amerika Serikat, industrial relation telah ada sejak akhir tahun 1920an, ada 3 perdebatan yang terjadi dalam masalah perBuruhan berkaitan dengan industrial relation, salah satunya adalah ketergantungan dan posisi tawar yang lemah dari Pekerja maupun Serikat Pekerja pada Peraturan Pemerintah (government regulation in the form protective labor legislation).

Di Jerman, sebagai bagian dari Civil Code, dalam the Protection Against Dismissal Act and the Employment Promotion Act, disebutkan bahwa batasan kontrak merupakan hal yang utama dalam labour relations. Argumen-argumen tersebut di atas jelas menekankan perbedaan Hubungan Kerja dengan Hubungan Industrial. Dalam Hubungan Industrial, tidak hanya sekedar terdapat hubungan hukum, akan tetapi peran serta Negara (dalam hal ini Pemerintah) diatur di dalamnya. Sedangkan dalam konteks Hubungan Kerja, terdapat hubungan hukum yang jelas yaitu hubungan hukum privat atau hubungan hukum keperdataaan, karena hubungan kerja didasarkan pada kontrak kerja atau perjanjian kerja.

Sebagai bagian dari perjanjian pada umumnya, maka perjanjian kerja harus mmemenuhi syarat sahnya suatu perjanjian sebagaimana diatur dalam Pasal 1320 KUHPerdata. Ketentuan ini juga tertuang dalam Pasal 51 ayat (1) dan (2) UndnagUndang Nomor 13 Tahun 2003, perjanjian kerja dibuat secara tertulis dan lisan. Perjanjian kerja yang dipersyaratkan secara tertulis dilaksanakan sesuai dengan peraturan Perundang-Undangan yang berlaku.

Hubungan kerja antara Pengusaha dengan Pekerja dalam perjanjian kerja waktu tertentu hanya berlangsung selama jangka waktu kontrak yang paling lama dua tahun dan dapat diperpanjang selama satu tahun, sehingga totalnya paling lama tiga tahun. Dalam Pasal 58 ayat (1) dan (2) Undang-Undang Ketenagakerjaan, perjanjian kerja waktu tertentu tidak dapat mensyaratkan adanya masa percobaan kerja. Apabila disyaratkan masa percobaan kerja dalam perjanjian kerja, maka masa percobaan kerja yang disyaratkan batal demi hukum. Ada 3 jenis Pekerja/Buruh dengan Perjanjian Kerja Waktu Tertentu, yaitu: 
1) Pekerja/Buruh kontrak yaitu Pekerja/Buruh yang diPekerjakan sesuai dengan jangka waktu yang disepakati dalam kontrak.

2) Pekerja/Buruh harian lepas yaitu Pekerja/Buruh yang bekerja pada Pengusaha untuk melaksanakan Pekerjaan tertentu yang dapat berubah-ubah dalam hal waktu maupun volume Pekerjaan, dengan menerima upah yang didasarkan atas kehadiran Pekerja secara harian. Pekerja/Buruh harian lepas ini sering kali terdapat pada Perusahaan-Perusahaan kontraktor yang sedang mengerjakan proyek (bangunan, jalan umum, dan lain-lain).

3) Pekerja/Buruh borongan, yaitu Pekerja/Buruh atau sejumlah Pekerja/Buruh yang bekerja pada suatu Perusahaan dengan memborong suatu jenis Pekerjaan tertentu yang dapat diukur dengan banyaknya atau jumlahnya atau ukurannya atau beratnya. Hubungan kerja antara Pekerja/Buruh dengan Pengusaha ini akan berakhir apabila Pekerjaan borongannya telah selesai dikerjakan.

Perjanjian kerja untuk waktu tidak tertentu adalah perjanjian yang jangka waktu berlakunya tidak disebutkan dalam perjanjian kerja, tidak menyebutkan beberapa lama tenaga kerja harus melakukan pekerjaan tersebut. ${ }^{10}$ Perjanjian kerja waktu tidak dibuat untuk Pekerja tetap. Dalam Pasal 60 ayat (1) Undang-Undang Ketenagakerjaan, perjanjian kerja waktu tidak tertentu dapat mensyaratkan masa percobaan kerja paling lama 3 (tiga) bulan dan harus dicantumkan dalam perjanjian kerja. Bila perjanjian kerja dilakukan scara lisan, maka syarat masa percobaan kerja harus diberitahukan kepada Pekerja yang bersangkutan dan dicantumkan dalam surat pengangkatan. ${ }^{11}$ Penting juga diketahui bahwa dalam masa percobaan kerja, Pengusaha dilarang membayar upah dibawah upah minimum yang berlaku. Sebaliknya jika dalam perjanjian tidak disebutkan masa percobaan dan hal tersebut juga tidak dicantumkan dalam pengangkatan, maka masa dianggap tidak ada. Dalam Pasal 61 ayat (1) Undang-Undang Ketenagakerjaan menyebutkan hal-hal yang menyebabkan berakhirnya perjanjian kerja yaitu:

1) Pekerja meninggal dunia

2) Berakhirnya jangka waktu perjanjian kerja

10 Sendjun H. Manulang, Pokok-Pokok Hukum Ketenagakerjaan di Indonesia, Jakarta: PT. Rineka Cipta, 1995, hlm. 69.

11 Asri Wijayanti, Hukum Ketenagakerjaan Pasca Reformasi, Jakarta: Sinar Grafika,2010,hlm.52 
3) Adanya putusan pengandilan dan/atau putusan/penetapan lembaga penyelesaian perselisihan hubungan industrial yang mempunyai kekuatan hukum tetap

4) Adanya keadaan atau kejadian tertentu yang dicantumkan dalam perjanjian kerja, peraturan Perusahaan, perjanjian kerja bersama yang dapat menyebabkan berakhirnya hubungan kerja.

Selain hal tersebut diatas, mengenai berakhirnya suatu hubungan kerja juga diutarakan dalam sebuah buku karangan Agn. B. Nemen Florencianoy Gloria, dimana menyebukan hal-hal yang menyebabkan berakhirnya perjanjian kerja waktu tidak tertentu antara lain sebagai berikut:

1) Pekerja meninggal dunia

2) Adanya putusan pengadilandan/atau putusan/penetapan lembaga penyelesaian perselisihan hubungan industrial yang mempunyai kekuatan hukum tetap

3) Adanya keadaan atau kejadian tertentu yang dicantumkan dalam perjanjian kerja, peraturan penrusahaan, perjanjian kerja bersama seperti bencana alam, kerusuhan sosial atau gangguan keamanan.

Sesuai dengan ketentuan pasal 1 angka 14 Undang-Undang Nomor 13 tahun 2003, bahan perjanjian kerja adalah perjanjian (yang dibuat) antara Pekerja/Buruh dengan Pengusaha atau pemberi kerja yang memuat syarat-syarat kerja, hak dan kewajiban para pihak (Pengusaha dan Pekerja atau Buruh). Dengan demikian salah satu inti dari perjanjian kerja adalah adanya klausul-klausul yang mengatur hak-hak dan kewajiban masing-masing pihak secara bertimbal balik. Demikian juga mengatur mengenai syaratsyarat kerja, termasuk tata tertib dalam melakukan Pekerjaan di Perusahaan. Rincian isi syarat dari perjanjian kerja dimaksud sebagaimana tersebut dalam pasal 54 ayat (1) Undang-Undang Nomor 13 tahun 2003, bahwa perjanjian kerja yang dibuat secara terbukti, sekurang-kurangnya memuat:
a. Nama, alamat Perusahaan, dan jenis usaha
b. Nama, jenis kelamin, umur, dan alamat Pekerja/Buruh
c. Jabatan atau jenis Pekerjaan
d. Tempat Pekerjaan
e. Besarnya upah dan cara pembayarannya 
f. Syarat-syarat kerja yang memuat hak dan kewajiban Pengusaha dan Pekerja/Buruh

g. Mulai dan jangka waktu berlakunya perjanjian kerja

h. Tempat dan tanggal perjanjian kerja dibuat, dan

i. Tanda tangan para pihak dalam perjanjian kerja

Selanjutnya rincian dan ketentuan-ketentuan lebih lanjut mengenai syarat-syarat kerja serta hak-hak dan kewahiba para pihak, termasuk tata tertib Perusahaan, diatur lebih rinci dalam peraturan Perusahaan atau dalam perjanjian kerja bersama (PP/PKB), sbb.:

a. Perjanjian Kerja Bersama (PKB)

Perjanjian Kerja Bersama (PKB) adalah suatu kesepakatan secara tertulis dengan menggunakan bahasa Indonesia yang dibuat secara bersama-sama antara Pengusaha atau beberapa Pengusaha dengan organisasi serikat Pekerja/gabungan organisasi serikat Pekerja yang sudah terdaftar pada instansi yang bertanggung jawab dibidang ketenagakerjaan. Adapun dasar dibuatnya perjanjian Kerja Bersama ini merujuk pada Undang-Undang Nomor 18 Tahun 1956 yang diratifikasi dari Konvensi Nomor 98 Organisasi PerBuruhan Internasional (ILO) mengenai berlakunya dasar-dasar dari hak untuk berorganisasi dan berunding bersama, Kemudian oleh pemerintah dikeluarkan:

1) Undang-Undang Nomor 13 Tahun 2003 tentang Ketenagakerjaan yang diatur mulai dari pasal 115 sampai dengan 135;

2) Keputusan Menteri Tenaga Kerja dan Transmigrasi RI Nomor Kep/48/Men/IV/2004 tentang Tata Cara Pembuatan dan Pengesahan Peraturan Perusahaan dan Pendaftaran Perjanjian Kerja Bersama.

Fungsi Perjanjian Kerja Bersama adalah sarana untuk memuat dan menuangkan kesepakatan baru yang didasari atas kesepakatan antara serikat Pekerja/Buruh dengan Pengusaha yang disebut Lex Special artinya sebuah prodak yang tidak diatur dalam Undang-Undang maka dia akan menjadi normatif bila mana sudah disepakati dan dituangkan dalam PKB serta telah diketahui oleh Dinas yang terkait dan mengikat kedua belah pihak untuk dilaksanakan. 
Tujuan pembuatan Perjanjian Kerja Bersama :

1) Mempertegas dan memperjelas hak-hak dan kewajiban Pekerja dan Pengusaha

2) Memperteguh dan menciptakan hubungan industrial yang harmonis dalam Perusahaan

3) Menetapkan secara bersama syarat-syarat kerja keadaan industrial yang harmonis dan atau hubungan ketenagakerjaan yang belum diatur dalam peraturan Perundang-Undangan.

Manfaat Perjanjian Kerja Bersama :

1) Baik Pekerja maupun Pengusaha akan lebih memahami tentang hak dan kewajiban masing-masing;

2) Mengurangi timbulnya perselisihan hubungan industrial atau hubungan ketenagakerjaan sehingga dapat menjamin kelancaran proses produksi dan peningkatan usaha;

3) Membantu ketenangan kerja Pekerja serta mendorong semangat dan kegaitan bekerja yang lebih tekun dan rajin;

4) Pengusaha dapat menganggarkan biaya tenaga kerja (labour cost) yang perlu dicadangkan atau disesuaikan dengan masa berlakunya PKB.

\section{b. Peraturan Perusahaan}

Peraturan Perusahaan merupakan tindak lanjut dari perjanjian kerja, karena pada prinsipnya perjanjian kerja hanya memuat mengenai syarat-syarat kerja yang sederhana, misalnya mengenai upahnya, Pekerjaannya, dan pembagian lain-lain (Emolumenten). Jadi dengan keadaan tersebut maka secara otomatis Peraturan Perusahaan memuat halhal yang lebih lengkap mengenai syarat-syarat kerja. Tujuan utama pembuatan Peraturan Perusahaan adalah mewujudkan kepastian syarat-syarat kerja di Perusahaan, di mana syarat-syarat kerja tersebut tentunya tidak bertentangan dengan peraturan Perundang-Undangan yang berlaku, atau bahkan lebih baik darinya.untuk melindungi Pekerja/Buruh dari syarat-syarat kerja yang tidak baik atau bertentangan dengan peraturan Perundang-Undangan yang berlaku, maka Peraturan Perusahaan yang telah dibuat wajib disahkan oleh instansi pemerintah yang bertanggung jawab di bidang ketenagakerjaan setempat. Adapun manfaat Peraturan Perusahaan baik bagi Pengusaha 
maupun Pekerja/Buruh antara lain sebagai berikut :

1) Sebagai pedoman hak dan kewajiban bagi Pengusaha dan Pekerja/Buruh, sehingga masing-masing pihak akan mampu memahami dan melaksanakan hak dan kewajibannya masing-masing.

2) Sebagai sarana untuk mencipatakan ketenangan bekerja dan kelangsungan usaha. Dengan adanya Peraturan Perusahaan, bila terjadi suatu perselisihan, maka Pengusaha dan Pekerja/Buruh dapat segera menyelesaikannya dengan mendasarkan kepada Peraturan Perusahaan yang berlaku. Hal yang demikian diharapkan dapat mengurangi terjadinya perselisihan hubungan industrial yang berkembang karena tidak mampu diselesaikan secara bipartit.

3) Sebagai sumber data bagi Pengusaha untuk menyusun rencana dalam menetapkan labour cost yang perlu dicadangkan atau disesuaikan dengan masa berlakunya Peraturan Perusahaan.

4) Sebagai tahap permulaan terwujudnya PKB di Perusahaan. Di Perusahaan yang telah ada SP/SB, Pengusaha wajib memenuhi kehendak SP/SB yang meminta merundingkan pembuatan $\mathrm{PKB}$, jika SP/SB tersebut mengajukan permintaan secara tertulis, meskipun masa berlaku Peraturan Perusahaan belum habis. PKB yang telah disepakati antara Pengusaha dengan SP/SB dapat menggantikan kedudukan Peraturan Perusahaan. Pembuatan Peraturan Perusahaan merupakan tujuan antara yang bersifat anvullend, selama PKB belum dapat diwujudkan di Perusahaan karena tidak adanya SP/SB.

Tidak semua Perusahaan dikenai kewajiban membuat Peraturan Perusahaan. Hanya Perusahaan-Perusahaan tertentu yang memenuhi syarat yang telah ditetapkan oleh peraturan Perundang-Undangan. Jadi, tidak semua Perusahaan karena ada Perusahaan yang tidak memenuhi syarat wajib membuat Peraturan Perusahaan. Berdasarkan Pasal 108 Undang-Undang Nomor 13 Tahun 2003 tentang Ketenagakerjaan, kriteria Perusahaan yang wajib membuat Peraturan Perusahaan adalah sebagai berikut :

1) MemPekerjakan Pekerja/Buruh sekurang-kurangnya 10 (sepuluh) orang. Kriteria pertama Perusahaan yang wajib memiliki Peraturan Perusahaan adalah memiliki Pekerja/Buruh sekurang-kurangnya 10 (sepuluh) orang. Jumlah tersebut menjadi 
penentu apakah sebuah Perusahaan telah dikenai kewajiban membuat Peraturan Perusahaan atau tidak, tanpa perlu memperhatikan faktor-faktor lain semisal jumlah modal, omzet, bonafid atau tidak, dan lain sebagainya. Asalkan jumlah tenaga kerja telah mencapai minimal 10 (sepuluh) orang, maka menurut UndangUndang, Perusahaan tersebut wajib memiliki Peraturan Perusahaan.

2) Perusahaan tersebut tidak memiliki Perjanjian Kerja Bersama (PKB). Perjanjian Kerja Bersama (PKB) menurut Undang-Undang Nomor 13 Tahun 2003 tentang Ketenagakerjaan didefinisikan sebagai perjanjian yang merupakan hasil perundingan antara SP/SB atau beberapa SP/SB yang tercatat pada instansi yang bertanggung jawab di bidang ketenagakerjaan dengan Pengusaha, atau beberapa Pengusaha atau perkumpulan Pengusaha yang memuat syarat-syarat kerja, hak dan kewajiban kedua belah pihak.

Perjanjian kerja dapat dibuat dalam bentuk lisan dan/atau tertulis (Pasal 1 Undang-Undang Nomor 13 Tahun 2003). Secara normatif bentuk tertulis menjamin kepastian hak dan kewajiban para pihak, sehingga jika terjadi perselisihan akan sangat membantu proses pembuktian.

Dalam Pasal 54 Undang-Undang Nomor 13 Tahun 2003 tentang Ketenagakerjaan menyebutkan bahwa perjanjian kerja yang dibuat secara tertulis sekurang-kurangnya memuat keterangan:

a. Nama, alamat, Perusahaan dan jenis usaha;

b. Nama, jenis kelamin, umur, dan alamat Pekerja/Buruh;

c. Jabatan atau jenis Pekerjaan;

d. Tempat Pekerjaan;

e. Besarnya upah dan cara pembayaran;

f. Syarat-syarat kerja yang memuat hak dan kewajiban Pengusaha dan Pekerja/Buruh;

g. Mulai dan jangka waktu berlakunya perjanjian kerja;

h. Tempat dan tanggal perjanjian kerja dibuat;

i. Tanda tangan para pihak dalam perjanjian kerja.

Perjanjian kerja yang dibuat untuk waktu tertentu lazimnya disebut dengan 
perjanjian kontrak atau perjanjian kerja tidak tetap. Status Pekerjaannya adalah Pekerjaan tidak tetap atau Pekerja kontrak. Sedangkan perjanjian kerja yang dibuat untuk waktu tidak tertentu biasanya disebut dengan perjanjian kerja tetap dan status Pekerjaan adalah Pekerja tetap.

Dengan memperhatikan hubungan ketenagakerjaan antara Pekerja waktu tertentu dan waktu tidak tertentu pada Perseroan Terbatas, diketahui bahwa hubungan hukum tersebut selalu diikat oleh suatu perjanjian kerja secara tertulis. Hal ini menunjukkan bahwa sekalipun Pasal 51 Undang-Undang Nomor 13 Tahun 2003 tentang Ketenagakerjaan memungkinkan adanya perjanjian secara lisan, namun kedua belah pihak (Pekerja dan Perusahaan) sepakat memilih untuk menggunakan perjanjian berbentuk tertulis. Perjanjian tertulis antara Pekerja dan Perusahaan tersebut secara khusus dibuat untuk masing-masing jenis perjanjian.

Dengan memilih membuat perjanjian kerja secara tertulis, maka dokumen surat perjanjian tersebut memiliki beberapa kelebihan, seperti dokumen perjanjian tersebut dapat dikategorikan sebagai kontrak sebagaimana disebutkan oleh Prof. Subekti. ${ }^{12}$ Sebagai suatu kontrak maka dokumen perjanjian kerja tertulis tersebut memiliki kekuatan mengikat yang tinggi, dan karenanya dapat menjadi alat bukti yang kuat di pengadilan apabila salah satu pihak diduga melakukan wanprestasi.

Dijelaskan pada bab III, bahwa dalam perjanjian kerja tersebut memuat data para pihak, yaitu Pekerja akan tunduk pada perintah Perusahaan pemberi kerja, Pekerjaan yang harus diselesaikan, serta upah yang disepakati. Dengan adanya ketiga unsur tersebut, maka perjanjian kerja pada Perseroan Terbatas ini memenuhi syarat untuk disebut sebagai perjanjian sebagaimana dikemukakan oleh FX Djumialdy, SH, M.Hum. ${ }^{13}$ Semikian pula dikaitkan dengan pendapatnya Kartini Muljadi dan Gunawan, maupun PNH Simanjuntak SH maka unsur-unsur yang ada pada perjanjian kerja pada Perseroan Terbatas ini menunjukkan suatu bentuk perjanjian pada umumnya.

Para pihak yang ada dalam perjanjian kerja adalah Pekerja di satu pihak dan direktur utama dipihak lain, jika perjanjian kerja waktu tidak tertentu, atau direktur utama dipihak lain, jika perjanjian kerja waktu tidak tertentu, atau direktur operasional, jika perjanjian kerja waktu tertentu. Sebagaimana diatur dalam Pasal 1320 Kitab Undang-Undang Hukum Perdata, bahwa untuk sahnya suatu perjanjian maka perjanjian

12 Subekti, Hukum Perjanjian, Cet. XXII, Jakarta: Intermasa, 2008, hlm. 1.

13 FX Djumialdi, Perjanjian Kerja, Jakarta : Bumi Aksara, 1997, hlm. 7-8. 
harus memenuhi 4 syarat, yaitu: ${ }^{14}$
a. Sepakat mereka yang mengikatkan dirinya
b. Kecakapan untuk membuat suatu perikatan
c. Suatu hal tertentu
d. Suatu sebab yang halal.

Syarat sepakat mereka yang mengikatkan dirinya sudah terpenuhi karena kedua belah pihak sudah sepakat yang ditandai dengan menandatangani perjanjian kerja. Syarat suatu hal tertentu terpenuhi karena hal yang diperjanjikan jelas, yaitu adanya objek yang jelas, dalam hal ini untuk melakukan suatu Pekerjaan. Syarat suatu sebab yang halal juga terpenuhi karena yang diperjanjikan adalah suatu Pekerjaan yang tidak bertentangan dengan ketertiban umum, kesusilaan, dan Undang-Undang.

Syarat cakap menurut Kitab Undang-Undang Hukum Perdata adalah seseorang dikatakan cakap hukum apabila seseorang, laki-laki atau wanita telah berumur minimal 21 tahun, atau bagi seorang laki-laki apabila belum berumur 21 tahun telah melangsungkan pernikahan. Melihat para pihak yang menandatangani perjanjian kerja di Perseroan Terbatas, bahwa dari pihak Pekerja seluruhnya berusia diatas 21 tahun, dan mereka tidak dibawah pengampuan (curatele). Oleh karena itu, pihak Pekerja telah memenuhi syarat cakap dari aspek umur. Sementara itu, dari pihak Perusahaan yang menandatangani perjanjian adalah pihak yang mewakili subjek hukum Perusahaan (badan hukum), dalam hal ini para direrktur karena jabatannya mewakili subjek hukum Perusahaan.

Dalam hal direktur Perseroan Terbatas mewakili subjek hukum berbentuk badan hukum perseroan terbatas, kewenangan direktur telah diatur dalam Undang-Undang Nomor 40 Tahun 2007 tentang Perseroan Terbatas, serta anggaran dasar Perseroan Terbatas, yaitu direksi mewakili perseroan baik di dalam maupun di luar pengadilan. Mewakili di luar pengadilan ini termasuk diantaranya melakukan perikatan dengan Pekerja melalui penandatanganan perjanjian kerja.

Dalam bab III telah dijelaskan bahwa untuk perjanjian kerja dengan waktu tertentu, direktur yang menandatangani perjanjian kerja adalah Direktur Operasional, sedangakan untuk perjanjian kerja waktu tidak teretentu ditandatangani oleh Direktur

14 Kitab Undang-Undang Hukum Perdata, Pasal 1320. 
Utama. Alasan perbedaan pihak yang mewakili Perusahaan menurut manajemen Perseroan Terbatas adalah karena perjanjian kerja waktu tertentu melibatkan PekerjaPekerja operasi, sehingga akan lebih tepat jika Direktur Operasi yang menandatangani perjanjiannya. Perbedaan direktur yang mewakili Perusahaan ini menimbulkan pertanyaan apakah kedua direktur tersebut sama-sama secara hukum dapat dikatakan cakap untuk menandatangani perjanjian?.

Dengan mengacu pada prinsip bahwa kepemimpinan direksi pada perseroan adalah bersifat kolegial atau teman sejawat, Undang-Undang Nomor 40 Tahun 2007 Pasal 98 ayat (2) menyebutkan dalam hal anggota direksi terdiri dari lebih dari satu orang yang berwenang mewakili perseroan adalah setiap anggota direksi, kecuali ditentukan lain dalam anggaran dasar. Kemudian karena anggaran dasar Perusahaan mengatur hal yang sama dengan Pasal 98 ayat (2) di atas, maka baik Direktur Utama maupun Direktur Operasional adalah secara hukum dinyatakan cakap dalam menandatangani perjanjian.

Dalam uraian di atas, karena seluruh persyaratan sahnya suatu perjanjian telah terpenuhi, maka perjanjian kerja pada Perseroan Terbatas secara hukum telah menjadi suatu perjanjian yang sah.

\section{Terpenuhinya Unsur-unsur Perjanjian Kerja Menurut Undang-undang Nomor 13 Tahun 2003 Tentang Ketenegakerjaan Dalam Perjanjian Kerja Antara Perseroan Terbatas (PT) dengan Pekerja.}

Pada asasnya perjanjian hanya mengikat pihak-pihak yang membuatnya, seperti tampak dalam Pasal 1338 Ayat (1) KUH Perdata, hal ini juga ditegaskan dalam Pasal 1315 KUH Perdata. ${ }^{15}$ Perjanjian itu merupakan sumber perikatan yang terpenting, karena perikatan adalah suatu pengertian abstrak sedangkan perjanjian adalah suatu hal yang konkrit atau suatu peristiwa yang nyata mengikat para pihak yang membuat suatu perjanjian.

Di dalam terbentuknya suatu perjanjian adapun yang menjadi asas-asas dalam suatu perjanjian, yaitu: ${ }^{16}$

1. Asas Kebebasan Berkontrak

15 Chairun Pasribu dan Suharawardi Lubis, Hukum Perjanjian dalam Islam, Jakarta, 2011, hlm. 263.

16 Tagor Simanjuntak, Op.cit., hlm. 4. 
Pasal 1338 ayat (1) Kitab Undang-Undang Hukum Perdata menyatakan bahwa "Semua perjanjian yang dibuat secara sah berlaku sebagai Undang-Undang bagi mereka yang membuatnya". Pasal tersebut mengandung unsur bahwa asas kebebasan berkontrak memberikan kebebasan kepada para pihak untuk:
a. Membuat atau tidak membuat perjanjian
b. Mengadakan perjanjian dengan siapa pun
c. Menentukan isi perjanjian, pelaksanaan, dan persyaratan
d. Menentukan bentuk perjanjiannya

Awal mula lahirnya asas kebebasan berkontrak adalah adanya paham individualisme yang lahir sejak zaman Yunani. Menurut paham individualisme, setiap orang bebas memperoleh apa saja yang dikehendakinya. Dalam hukum kontrak asas ini diwujudkan dalam "kebebasan berkontrak". Pada akhir abad ke-19, akibat desakan paham etis dan sosialis, paham individualisme mulai pudar. Oleh karena itu, kehendak bebas tidak lagi berlaku secara mutlak, akan tetapi selalu dikaitkan dengan kepentingan umum. Dengan demikian, pengaturan substansi perjanjian tidak semata-mata dibiarkan kepada para pihak namun perlu juga diawasi.

\section{Asas Konsensualisme}

Pasal 1320 ayat (1) Kitab Undang-Undang Hukum Perdata menyatakan bahwa salah satu syarat sahnya perjanjian adalah adanya kata kesepakatan antara kedua belah pihak. Asas ini merupakan asas yang menyatakan bahwa perjanjian pada umumnya tidak diadakan secara formal, melainkan cukup dengan adanya kesepakatan kedua belah pihak. Kesepakatan adalah persesuaian antara kehendak dan pernyataan yang dibuat oleh kedua belah pihak. Asas Konsesualisme mucul dari hukum Romawi dan hukum Jerman. Dalam hukum Romawi dikenal isitlah contractus verbis literis dan contractus innominat yang artinya bahwa terjadinya perjanjian apabila memenuhi bentuk yang telah ditetapkan. Di dalam hukum Jerman dikenal perjanjian riil dan perjanjian formal. Perjanjian riil adalah perjanjian yang dibuat dan dilaksanakan secara nyata sedangkan perjanjian formal adalah perjanjian yang telah ditentukan bentuknya, yaitu secara tertulis.

3. Asas Kepastian Hukum

Pasal 1338 ayat (1) Kitab Undang-Undang Hukum Perdata mengatur tentang asas 
kepastian hukum. Asas kepastian hukum merupakan asas yang berhubungan dengan akibat perjanjian dari aspek hukum. Dalam asas ini, hakim atau pihak ketiga harus menghormati substansi kontrak yang dibuat oleh para pihak, sebagaimana layaknya sebuah Undang-Undang. Pihak ketiga tidak boleh melakukan intervensi terhadap substansi kontrak yang dibuat oleh para pihak.

\section{Asas Itikad Baik}

Asas itikad baik dijelaskan dalam Pasal 1338 ayat (3) Kitab Undang-Undang Hukum Perdata yang berbunyi:"Perjanjian harus dilaksanakan dengan itikad baik". Asas ini menerangkan bahwa para pihak, yaitu pihak kreditur dan debitur harus melaksanakan substansi kontrak berdasarkan kepercayaan atau keyakinan yang teguh maupun kemauan baik dari para pihak.

\section{Asas Kepribadian}

Pasal 1315 Kitab Undang-Undang Hukum Perdata menegaskan bahwa "Pada umumnya sesorang tidak dapat mengadakan perikatan atau perjanjian selain untuk dirinya sendiri". Pasal tersebut berisi ketentuan bahwa untuk mengadakan suatu perjanjian harus untuk mengadakan suatu perjanjian harus untuk kepentingan dirinya sendiri. Asas kepribadian menentukan bahwa seseorang yang akan melakukan atau membuat kontrak hanya dimaksudkan untuk kepentingan perseorangan saja.

\section{Asas Kesetaraan}

Asas ini menempatkan para pihak di dalam derajat yang sama, tidak ada perbedaan, meskipun memiliki perbedaan warna kulit, bangsa, kekayaan, kekuasaaan, jabatan, dan lain-lain. Masing-masing pihak wajib melihat adanya persamaan ini dan mengharuskan kedua pihak untuk menghormati satu sama lin. Asas ini dimaksudkan agar perjanjian dapat memberi keuntungan yang adil bagi semua pihak. Karena perjanjian pada hakikatnya adalah sebuah kerjasama bisnis untuk tujuan tertentu dan antara pihak yang terikat harus mempunyai kepentingan dan posisi yang sejajar.

Perjanjian-perjanjian dan asas-asas hukum perjanjian tersebut di atas, berlaku juga terhadap perjanjian kerja, walaupun dalam perjanjian kerja terdapat campur tangan kepemerintahan untuk memberikan perlindungan kepada pihak yang lemah (Pekerja).

Perjanjian kerja yang sah harus memenuhi syarat-syarat sahnya perjanjian secara umum sebagaimana diatur dalam Pasal 1320 Kitab Undang-undang Hukum Perdata (KUHPerdata), dan secara khusus harus memenuhi syarat-syarat yang dijelaskan dalam 
Pasal 52 Undang-Undang Nomor 13 Tahun 2003 tentang Ketenagakerjaan. Dalam pasal tersebut perjanjian kerja menjadi sah apabila ada kesepakatan kedua pihak, yaitu pengusaha dan pekerja/buruh. Syarat kesepakatan ini, baik menurut KUHPerdata maupun diikuti dengan syarat selanjutnya, yaitu adanya kemampuan atau kecakapan para pihak untuk melakukan perbuatan hukum. Kedua syarat ini disebut syarat subyektif, karena syarat ini berkaitan dengan orang-orang atau subyek yang mengatur perjanjian. ${ }^{17}$

Ketentuan dalam pasal 1320 tersebut sama dengan ketentuan yang diatur dalam pasal 52 (1) dan UU Nomor 13 tahun 2003 tentang Ketenagakerjaan. Secara khusus mengenai perjanjian kerja ini dalam Undang-Undang Nomor 13 tahun 2003 diatur sebagai berikut: ${ }^{18}$

1. Perjanjian kerja dibuat secara tertulis atau lisan.

2. Perjanjian kerja yang dipersyaratkan secara tertulis dilaksanakan sesuai dengan Peraturan Perundang-Undangan yang berlaku.

Selanjutnya Undang-Undang No. 13 tahun 2003 menyatakan:

1. Perjanjian kerja dibuat atas dasar:

a. Kesepakatan kedua belah pihak;

b. Kemampuan atau kecakapan melakukan perbuatan hukum;

c. Adanya pekerjaan yang diperjanjikan; dan

d. Pekerjaan yang diperjanjikan tidak bertentangan dengan ketertiban umum, kesusilaan, dan Peraturan Perundang-Undangan yang berlaku.

2. Perjanjian kerja yang dibuat oleh para pihak yang bertentangan dengan ketentuan sebagaimana dimaksud pada ayat (1) huruf a dan b dapat dibatalkan.

3. Perjanjian kerja yang dibuat oleh para pihak yang bertentangan dengan ketentuan sebagaimana dimaksud pada ayat (1) huruf c dan d batal demi hukum.

Syarat sahnya perjanjian kerja selanjutnya adalah adanya pekerjaan yang diperjanjikan. Dalam syarat berikutnya, yaitu pekerjaan yang diperjanjikan tidak bertentangan dengan ketertiban umum, kesusilaan, dan peraturan perundang-undangan.

17 Judiantoro, “Kebebasan Berkontrak Dalam Pembuatan Perjanjian Kerja (Suatu Analisis Perjanjian Kerja Sektor Industri),” Disertasi, Jakarta: Fakultas Hukum Universitas Indonesia, 2010, hlm. 98.

18 Republlik Indonesia, Undang-Undang Nomor 13 Tahun 2003 tentang Ketenagakerjaan. 
Kedua syarat terakhir ini, disebut sebagai syarat obyektif. Syarat obyeltif adanya pekerjaan yang diperjanjikan merupakan obyek perbuatan hukum yang dilakukan, yaitu perjanjian kerja.

Yang dimaksud dengan kemampuan atau kecakapan menurut hukum ketenagakerjaan, adalah orang yang sudah berumur 18 tahun, sehat pikirannya, dan tidak berada dibawah pengampuan. Undang-undang Ketenagakerjaan menyatakan anak adalah setiap orang yang berumur dibawah 18 tahun. Hal ini berbeda dengan ketentuan cakap dalam KUHPerdata, yaitu 21 tahun dan belum menikah.

Undang-undang ketenagakerjaan menyatakan anak berumur 13 tahun sampai dengan 15 tahun boleh melakukan pekerjaan ringan, sepanjang tidak mengganggu perkembangan dan kesehatan fisik, mental, dan sosial. Persyaratannya pekerja anak bekerja dalam waktu kerja maksimum 3 jam, ada waktu siang hari dan tidak mengganggu waktu sekolahnya. ${ }^{19}$

Menurut Undang-Undang Nomor 13 Tahun 2003 suatu perjanjian kerja waktu tertentu sekurang-kurangnya memuat:
a. Nama, alamat Perusahaan, dan jenis usaha
b. Nama, jenis kelamin, umur, dan alama Pekerjaan/Buruh
c. Jabatan atau jenis Pekerjaan Buruh
d. Tempat Pekerjaan
e. Besarnya upah dan cara pembayarannya
f. Syarat-syarat kerja yang memuat hak dan kewajiban Pengusaha dan Pekerja/Buruh
g. Mulai dan jangka waktu berlakunya perjanjian kerja
h. Tempat dan tanggal perjanjian kerja dibuat
i. Tanda tangan para pihak dalam perjanjian kerja

Dikaitkan dengan perjanjian kerja waktu tertentu pada Perseroan Terbatas diketahui bahwa persyaratan seperti di atas belum dipenuhi sepenuhnya. Beberapa hal yang belum tertera dalam perjanjian kerja tersebut adalah:
a. Jenis usaha Perusahaan
b. Jenis kelamin para pihak

19 Judiantoro, Op.cit., hlm. 100. 


\section{c. Tata cara pembayaran \\ d. Tempat terjadinya perjanjian kerja dibuat}

Selain fakta tidak dimasukannya beberapa persyaratan diatas, di dalam perjanjian kerja waktu tertentu masih ditemukan adanya klausula yang bertentangan dengan peraturan Perusahaan yaitu tentang Alat Pelindung Diri (APD). Menurut Pasal 1, 2, dan 3 Peraturan Menteri Tenaga Kerja dan Transmigrasi No.PER.08/MEN.VII/2010 tentang Alat Pelindung Diri (APD) Perusahaan wajib menyediakan APD sesuai Standar Nasional Indonesia secara cuma-cuma sebagai syarat perlindungan diri bagi karyawan dalam melakukan Pekerjaan. Pada kenyataannya Perusahaan tidak menyediakan APD sesuai Standar. Standar yang dimaksudkan yaitu tidak sesuai dengan Standar Nasional Indonesia dan tidak sesuai standar jumlah (jumlah tidak memadai dibandingkan dengan jumlah karyawan). Perusahaan seharusnya menyediakan APD sesuai dengan pasal 2 ayat 2 Peraturan Menteri Tenaga Kerja dan Transmigrasi Nomor :PER.08/ MEN.VII/2010. Dalam penggunaan APD seharusnya sesuai dengan pasal 4 ayat 1 Peraturan Menteri Tenaga Kerja dan Transmigrasi No.PER.08/MEN.VII/2010. Berdasarkan pasal 6 ayat 2 Peraturan Menteri Tenaga Kerja dan Transmigrasi Nomor: PER.08/MEN.VII/2010 apabila Perusahaan tidak dapat menyediakan APD sesuai dengan standar maka karyawan dapat menolak melakukan Pekerjaan.

Menurut Undang-Undang Nomor 13 Tahun 2003, Pasal 1 angka 15, menyatakan bahwa hubungan kerja adalah hubungan antara majikan/Pengusaha dengan Pekerja/Buruh berdasarkan perjanjian kerja, yang mempunyai unsur Pekerjaan, upah dan perintah. Berdasarkan ketentuan Pasal 52 ayat (1), ayat (2) dan ayat (3) UndangUndang Nomor 13 Tahun 2003, syarat sahnya hubungan kerja adalah:

a. Kesepakatan kedua belah pihak

Kesepakatan kedua belah pihak yang lazim disebut kesepakatan bagi yang mengikatkan dirinya maksudnya bahwa pihak-pihak yang mengadakan perjanjian kerja harus setuju/ sepakat, seiya sekata mengenai hal-hal yang diperjanjikan. Pihak Pekerja menerima Pekerjaan yang ditawarkan dan pihak Pengusaha menerima Pekerja tersebut untuk diPekerjakan. ${ }^{20}$

b. Kemampuan atau kecakapan dalam melakukan perbuatan hukum

20 Lalu Husni, Pengantar Hukum Ketenagakerjaan Indonesia, Jakarta: Raja Grafindo Persada, 2003, hlm. 57. 
Kemampuan atau kecakapan kedua belah pihak yang membuat perjanjian maksudnya pihak Pekerja maupun Pengusaha cakap membuat perjanjian. Seseorang dipandang cakap membuat perjanjian jika yang bersangkutan telah cukup umur. Ketentuan hukum ketenagakerjaan memberikan batasan umur 18 tahun (Pasal 1 Angka 26 Undang-Undnag Nomor 13 Tahun 2003).

c. Adanya Pekerjaan yang diperjanjikan

Perjanjian yang diperjanjikan merupakan obyek dari perjanjian kerja antara Pekerja dengan Pengusaha, yang akibat hukumnya melahirkan hak dan kewajiban para pihak. Perjanjian yang dijanjikan tidak bertentangan dengan kepentingan umum, kesusilaan, dan peraturan Perundang-Undangan yang berlaku.

d. Objek perjanjian harus halal

Bahwa tidak boleh bertentangan dengan Undang-Undang, ketertiban umum dan kesusilaan. Jenis Pekerjaan yang diperjanjikan merupakan salah satu unsur perjanjian kerja yang harus disebutkan secara jelas.

Syarat tersebut secara keseluruhan wajib terpenuhi untuk membuat sebuah perjanjian yang sah menurut hukum. Perjanjian kerja yang dibuat para pihak yang bertentangan dengan ketentuan yaitu adanya kesepakatan kedua belah pihak dengan adanya kemampuan atau kecakapan melakukan perbuatan hukum dapat dibatalkan.

Syarat adanya Pekerjaan yang diperjanjikan dan Pekerjaan yang diperjanjikan tidak boleh bertentangan dengan ketertiban umum, kesusilaan, dan peraturan Perundang-Undangan yang berlaku merupakan syarat obyektif karena menyangkut obyek perjanjian, kalau obyek perjanjian tidak terpenuhi, maka perjanjian itu batal demi hukum. Artinya sejak semula perjanjian itu dianggap tidak pernah ada. ${ }^{21}$ Dengan perjanjian kerja maka akan menimbulkan hubungan kerja antara Pekerja/ Buruh dengan Pengusaha yang berisi hak-hak dan kewajiban bagi masing-masing pihak. Demikian pula sebaliknya kewajiban pihak yang satu merupakan hak bagi pihak yang lainnya.

Unsur-unsur perjanjian kerja yang menjadi dasar hubungan kerja sesuai dengan ketentuan Pasal 1 angka 4 Undang-Undang Nomor 13 Tahun 2003 tentang Ketenagakerjaan adalah: ${ }^{22}$

a. Adanya Pekerjaan (arbeid);

21 Ibid., hlm. 58-59. 36-37.

22 Asri Wijayanti, Hukum Ketenagakerjaan Pasca Reformasi, Jakarta: Sinar Grafika, 2010, hlm. 
Yaitu Pekerjaan bebas sesuai dengan kesepakatan Buruh dan majikan, asalkan tidak bertentangan dengan ketertiban umum, kesusilaan, dan peraturan PerundangUndangan yang berlaku.

b. Dibawah perintah/ gejag verhouding (maksudnya Buruh melakukan Pekerjaan atas perintah majikan, sehingga bersifat subordinasi);

di dalam hubungan kerja kedudukan majikan adalah pemberi kerja, sehingga ia berhak dan sekaligus berkewajiban untuk memberikan perintah-perintah yang berkaitan dengan Pekerjanya. Kedudukan Buruh sebagai pihak yang menerima perintah untuk melaksanakan Pekerjaan.

c. Adanya upah tertentu/ loan (adanya upah tertentu yang menjadi imbalan atas Pekerjaan yang telah dilakukan oleh Buruh);

Pengertian upah berdasarkan ketentuan Pasal 1 angka 30 Undang-Undang Nomor 13 Tahun 2003 adalah hak Pekerja/ Buruh yang diterima dan dinyatakan dalam bentuk uang sebagai imbalan dari Pengusaha atau pemberi kerja kepada Pekerja atau Buruh yang ditetapkan dan dibayarkan menurut suatu perjanjian kerja.

d. Dalam waktu (tijd) yang ditentukan (dapat tanpa batas waktu/ pensiun atau berdasarkan waktu tertentu)

Buruh bekerja untuk waktu yang ditentukan atau untuk waktu yang tidak tertentu atau selama-lamanya.

Ketentuan mengenai isi perjanjian kerja tersebut diatas berlaku untuk semua pengusaha, baik yang berbadan hukum maupun yang berbadan hukum. Dalam hal perjanjian kerja yang dibuat oleh Perseroan Terbatas, maka juga harus memenuhi syarat-syarat sebagaimana diatur oleh perundang-undangan.

Apabila suatu Perusahaan tidak memenuhi Peraturan Perundang-Undangan mengenai perancangan Perjanjian Kerja Perusahaan tersebut, maka sanksi yang diterima yaitu pembatalan suatu ikatan yang sah namun tidak sesuai dengan Peraturan PerundangUndangan tersebut dan diberikan keharusan untuk memperbarui Perjanjian Kerja tersebut dengan penyesuaian berdasarkan Undang-Undang Nomor 13 Tahun 2003 tentang Ketenagakerjaan dan Perjanjian Kerja yang telah diperbarui tersebut batal demi Hukum. 


\section{SIMPULAN}

Penelitian mengenai implementasi undang-undang ketenagakerjaan dalam perjanjian kerja antara perusahaan dan tenaga kerja di Perseroan Terbatas (PT), tim peneliti menyimpulkan sebagai berikut:

1. Pelaksanaan Perjanjian Kerja di PT telah dibuat secara tertulis, meskipun saat ini masih ditemukan beberapa perusahaan yang mencantumkan dalil-dalil perjanjian kerja antara perusahaan dan karyawan yang bertentangan dengan Undang-Undang Nomor 13 Tahun 2003 Tentang Ketenagakerjaan. Dalil-dalil tersebut berkaitan dengan cuti karyawan. Dalam isi perjanjian kerja tersebut Perusahaan menetapkan bahwa perusahaan tidak membayarkan cuti karyawan yang belum diambil atau gugur. Namun, karyawan berhak mendapatkan uang penggantian hak sesuai dengan ketentuan perundang-undangan. Untuk ketentuan-ketentuan mengenai waktu kerja, perjanjian kerja yang dibuat oleh PT telah mencantumkannya. Sehingga tenaga kerja dapat lebih mengetahui kewajiban yang harus dilaksanakan dalam bekerja. Selain itu, tenaga kerja juga tidak dapat dikenakan sanksi oleh perusahaan terhadap perbuatan-perbuatan yang tidak tertulis aturannya dalam Perjanjian Kerja. Sehingga dengan adanya Perjanjian Kerja yang dibuat oleh Persoran Terbatas (PT) dapat memberikan perlindungan hukum kepada tenaga kerja di perusahaan tersebut.

2. Unsur-unsur Perjanjian Kerja dalam Perjanjian Kerja di Perseroan Terbatas harus memenuhi unsur-unsur perjanjian sebagaimana diatur dalam Undang-undang Nomor 13 Tahun 2003 tentang Ketenegakerjaan. Perseroan Terbatas yang membuat perjanjian kerja tidak sesuai dengan peraturan perundang-undangan yang berlaku, maka perjanjian kerja tersebut batal demi hukum.

\section{DAFTAR PUSTAKA}

\section{Buku:}

Djumialdi, FX. 1997. Perjanjian Kerja. Jakarta: Bumi Aksara

Hardijan. 2004. Hukum Ketenagakerjaan. Jakarta: Ghalia Indonesia

Husni, Lalu. 2003. Pengantar Hukum Ketenagakerjaan Indonesia. Jakarta: Raja Grafindo Persada 
Khakim, Abdul. 2014. Dasar-Dasar Hukum Ketenagakerjaan Indonesia, Bandung: PT Citra Aditya Bakti

Manulang, Sendjun H. 1995. Pokok-Pokok Hukum Ketenagakerjaan di Indonesia. Jakarta: PT. Rineka Cipta

Pasribu, Chairun S. L. 2011. Hukum Perjanjian dalam Islam. Jakarta

Simanjuntak, Tagor. 2014. Draft Surat Perjanjian Segala Urusan. Yogyakarta: Aksara Sukses

Simatupang, Richard Burton. 2007. Aspek Hukum Dalam Bisnis. Jakarta: Rineka Cipta

Subekti, R. 2008. Cet. XXII. Hukum Perjanjian. Jakarta: Intermasa

Wijayanti, Asri. 2010. Hukum Ketenagakerjaan Pasca Reformasi. Jakarta: Sinar Grafika

Winarni, F. 2006. Administrasi Gaji dan Upah, Yogyakarta: Pustaka Widyatama

\section{Disertasi:}

Judiantoro, "Kebebasan Berkontrak Dalam Pembuatan Perjanjian Kerja (Suatu Analisis Perjanjian Kerja Sektor Industri)," Disertasi, Jakarta: Fakultas Hukum Universitas Indonesia, 2010

\section{Peraturan Perundang-undangan}

Kitab Undang-Undang Hukum Perdata (Burgerlijk Wetboek)

Republik Indonesia, Undang-Undang No.13 tahun 2003 tentang Ketenagakerjaan

\section{Internet:}

"Hubungan Kerja dan Perjanjian Kerja dalam Perspektif Hubungan Industrial," http://sekartrisakti.wordpress.com, diakses tanggal 24 September 2014 